\title{
ТЕОРЕТИКО-МЕТОДОЛОГІЧНІ АСПЕКТИ ПЛАСТИЧНОЇ ВИРАЗНОСТІ В МАЙСТЕРНОСТІ АКТОРА
}

\author{
Олена Абрамович ${ }^{1 a}$, Аліна Кудренко² \\ ${ }^{1}$ кандидат педагогічних наук, доцент; \\ e-mail: elenaabramovic20@gmail.com; ORCID: 0000-0002-4814-6709 \\ ${ }^{2}$ магістр; e-mail: kudrenko.alina@gmail.com; ORCID: 0000-0002-0288-8061 \\ а Київський національний університет культури і мистецтв, Київ, Україна \\ ь Театр-студія «Колоритми», Київ, Україна
}

\begin{abstract}
Анотація
У статті розглядають пластичну культуру як складову сценічного мистецтва в площині створення просторових форм художнього твору, індивідуального творчого трактування та внутрішнього стану актора. Пластику розглядають як ефективний інструмент виховання актора та формування його зовнішньої техніки, з чим пов'язані новітні пошуки й експерименти. Метою роботи є освоєння теоретичних знань, принципів пластичної майстерності сучасного актора. Методологія полягає в системному використанні комплексних методів дослідження пластичної культури актора: історико-культурного - для дослідження історичної динаміки розвитку пластичної культури актора; аналітичного - для опрацювання культурологічної, мистецтвознавчої та театрознавчої наукової літератури, а також опрацювання архівних матеріалів; джерелознавчого - для вивчення джерельної бази дослідження; типологічного методу, що посприяв виявленню чинників, які впливають наформування сценічноїпластики актора; методу наукового спостереженнята аналізу, що надало можливість з'ясувати особливостіпластичної виразностів вонтекстії двоїстоїприроди (як тілесної, так і чуттєвої); системного методу, що посприяв дослідженню особливостей інтеграції складових пластичної культури в процесі створення сценічного образу; методу теоретичного узагальнення - для підбиття підсумків дослідження. Наукова новизна полягає в теоретичному обґрунтуванні специфіки сценічної пластики у виконавському мистецтві актора відповідно до актуальних світових тенденцій. Висновки. Пластична майстерність актора (створення пластичного малюнку ролі) забезпечує передусім тренування психічних і психофізичних навичок, що сприяє вдосконаленню пластичності тілесного апарату виконавця, здатності адаптуватися до виконання будь-яких пластичних завдань. Пластичність - це головна якість, що характеризує рівень пластичної культури актора. Сценічна пластика в майстерності актора - це система взаємопов'язаних знань, фізичних навичок і вмінь, психологічних, моральних та естетичних якостей виконавця, що сприяють створенню художнього сценічного образу. Двоїста природа пластичної виразності: тілесна (у розумінні моторна) та чуттєва (тобто психоемоційна), що дає змогу презентувати її як своєрідне художнє зображення. Пластична культура - це комплекс спеціальних теоретичних знань та практичних навичок танцювально-пластичного та рухового характеру, необхідних актору для творчого осмислення пластичного образу персонажа.
\end{abstract}

Ключові слова: пластична майстерність актора; пластичний малюнок ролі; художній образ 


\section{Постановка проблеми}

Пошук нових форм сценічної виразності став характерною рисою еволюції загальносвітового театрального процесу на межі XX-XXI ст. Представники режисури різних театральних шкіл усе частіше звертаються до засобів пластичної виразності як одного з найефективніших у сценічному мистецтві. Пластично-просторові форми художнього твору індивідуалізують трактування ролі, відображаючи внутрішній світ персонажа, його переживання, думки, почуття та характер. Характеристика сценічної пластичної культури актора викликає увагу дослідників театру протягом останніх десятиліть.

\section{Аналіз останніх досліджень і публікацій}

У наукових дослідженнях під різним кутом зору вивчається питання еволюції пластичних засобів виразності в мистецтвах. Наприклад, Євген Гула $(2017$, с.914919) «від наскального живопису до фундаменту будь-якої мистецької творчості» в історичному контексті досліджує історичну еволюцію пластики в мистецтві України загалом та в окремих напрямах пластичних мистецтв, зокрема, у графіці, скульптурі та живописі. Питання пластичної виразності в театральному мистецтві порушено в роботах Й. Іттена, О. Лоуена, А. Михайлової, Г. Морозової, В. Нікітіна, О. Ремеза, М. Сулімова та інших. Специфіка пластичної культури актора протягом багатьох десятиліть викликала неабияку увагу наукової спільноти. Пластичну виразність у роботі актора, уміння володіти своїм тілом досліджено в роботах Б. Голубовського, А. Дрозніна, Г. Морозової, О. Немеровського, І. Рутберга та інших. С. Андрачников, Р. Біль, Л. Грачева, М. Козлов, Г. Морозова (1998) досліджують питання сценічної пластичності в контексті її ролі у процесі виховання артиста театру. Автори (Абрамович та Кудренко, 2019, с.133-136) цієї публікації досліджували особливості пластичної майстерності в акторському мистецтві початку XXI ст. та простежили їх еволюційні тенденції. Аналіз останніх публікацій засвідчує посилення інтересу вітчизняних та зарубіжних науковців до проблематики сценічної пластики. Це актуалізує дослідження сценічної пластики в сучасному театральному просторі.

Мета статті - проаналізувати, систематизувати та схарактеризувати історіографію основних теоретико-культурологічних досліджень, в яких наведено теоретикометодологічні аспекти пластичної майстерності актора.

\section{Виклад основного матеріалу}

Багатоаспектність проблематики пластичного виховання актора в сучасній театральній школі зумовила різноманітність підходів до її вивчення у працях вітчизняних і зарубіжних дослідників. Проблематику пластичної культури в контексті професійної підготовки майбутнього актора досліджував А. Бусол (2014, с.34-41) у науковій публікації «Сценічний рух як складова професійної підготовки студентів спеціальності акторська майстерність», в якій науковець узагальнює 
теорію та практику акторської майстерності, з'ясовуючи значення сценічного руху в процесі професійної підготовки актора. Автор стверджує, що сценічний рух є профілюючою складовою процесу виховання пластичної культури майбутніх акторів. Ю. Старостін (2016, с. 201-204) у статті «Акторський тренінг: його зміст та основа» досліджує характеристики акторського екзерсису К. Станіславського, Всеволода Меєрхольда та Л. Олійника в площині роботи актора над тілом та удосконаленням пластики. О. Мартинова (2000, с.80-82) у науковій публікації «Збереження традицій пластичного виховання актора в театральній школі» на основі аналізу педагогічних підходів провідних діячів театрального мистецтва першої половини XX ст. (С. Ейзенштейна, К. Станіславського, Всеволода Меєрхольда, О. Таїрова та $Є$. Вахтангова) визначає завдання підвищення пластичної культури актора та робить висновок про перспективи розвитку та збереження традицій театрального мистецтва засобами вдосконалення пластичної культури актора, що заснована на кращих школах найвизначніших практиків і теоретиків.

Стверджуючи, що головним завданням сучасної театральної педагогіки є формування в майбутніх акторів мистецтва володіння органікою у сценічній поведінці як найвищої форми майстерності, та акцентуючи на важливості танцю як компонента системи виражальних засобів драматичного мистецтва, Т. Благова $(2014$, с. 100) у науковій статті «Хореографічна підготовка в системі театральної освіти України» досліджує особливості танцювальної підготовки майбутніх діячів сценічного мистецтва та визначає місце і роль хореографії в системі вітчизняної театральної освіти. Посилаючись на наукову працю професора Ю. Громова (1976) «Виховання пластичної культури актора засобами танцю», в якій один з найвідоміших радянських хореографів, балетмейстерів і педагогів другої половини XX ст. акцентує на тому, що максимальне розширення форм та засобів сценічного вираження, що необхідні в процесі втілення багатоманітного, насиченого (психологічно та по-філософськи), складного за образно-дієвою структурою репертуару, є однією з тенденцій розвитку сучасного театру (Громов, 1976, с.7), дослідниця позиціонує хореографічно-пластичну підготовленість майбутнього актора необхідною професійною якістю та фокусує увагу на важливості вивчення різноманітних проявів хореографії в драматичному мистецтві, а головне - ролі танцю в процесі опанування майстерністю актора.

Окремі розділи пластичного виховання майбутнього актора на базі хореографічного мистецтва XX ст. - «Контакт-імпровізація», «Захоплення простору» та «Аргентинське танго», метою яких $€$ вивчення власного тіла, розміщення тіла в просторі та робота з партнером за допомогою трьох складових - музики, руху й акторської майстерності, розглядає О. Зиков (2008, с.221-230) у науковій розвідці «Завдання пластичного виховання акторів в контексті музики та акторської майстерності». Науковець акцентує на тому, що в навчанні майбутніх акторів танцювальне мистецтво відіграє лише прикладну роль, оскільки з усього його розмаїття виділяються лише ті аспекти, що, сприяючи фізичному вихованню, вихованню гнучкості, координації, уваги тощо, допомагають засобами пластики набути навичок акторської майстерності; найчастіше використовуються в драматичних театрах як танцювальні дивертисменти або танцювальні фрагменти, 
Вісник Київського національного університету культури і мистецтв.

Серія: Сценічне мистецтво

що характеризують історичну епоху або можуть бути застосовані для створення пластичної характеристики персонажа, створення повноцінної вистави в напрямку пластичної драми та ін.

Деякі аспекти означеного питання досліджує О. Касьянова (2015, с.52-62) устатті «Особливостіпластично-хореографічноїпідготовки співака-актора оперного жанру».

У науковомудослідженні «Виразнийрухяквзаємозв'язокруховихвластивостей та пластичних якостей актора» (Нижельской В.А., 2015, с.52-56) автор розглядає реалізацію системи пластичного виховання акторів у процесі навчання у вищій школі як відображення актором внутрішнього світу персонажа, його переживань, почуттів, думок і характерності через зовнішню виразність, поведінку на сцені, через рухи, пози та дії. Науковець презентує власну технологію навчання виразним рухам, акцентуючи, що спрямований розвиток фізичних здібностей у поєднанні з формуванням пластичних якостей підвищить успішність їх вивчення.

Феномену трансформування рухової діяльності в сценічних умовах на семіотичний текст і пов'язаних із цим проблем методики навчання майбутніх акторів основам сценічного руху та драматичної пластики присвячена публікація В. Ніжельського (2016а, с.189-193) «Пластичне виховання майбутніх акторів як фактор культурного перетворення фізичних дій на семіотичний текст». Дослідник стверджує, що вивчення та осмислення руху як знаку може посприяти вдосконаленню методики викладання фізичної культури акторам.

Способи органічного поєднання завдань і вимог дисциплін пластичного циклу з майстерністю актора пропонує М. Разночинцева $(2013$, с. 121-129) у статті «Роль пластики (сценічного руху) в навчанні акторській професії», а також наводить опис можливих варіантів таких поєднань на прикладах вправ та завдань сценічного руху.

Окрему групу джерел становлять наукові праці та публікації, в яких різноманітні аспекти пластичної культури актора розглянуто в історичній ретроспективі.

Проблематику процесу поетапної трансформації пластики акторів німецького театру і кіно періоду 1914-1922 рр. Е. Дойча, В. Крауса, К. Фейдта та інших досліджує Т. Соломкіна (2015) у публікації «Пластична виразність німецького експресіоністського актора на сцені і на екрані. 1914-1921 рр.». Авторка зазначає, що сценічний експресіонізм сформувався спираючись на попередній досвід живопису - сфокусувавшись на обличчі та напруженні окремих частин тіла виконавця (кисті рук, ліктя, коліна); у балетному театрі виникає специфічна пластика вираження внутрішнього світу героя, яку переймає і драматичний театр.

В. Торгашов (2013) у статті «Аналіз стану сценічної пластики в сучасній драматичній виставі (на матеріалі історичного етикету та стильової поведінки)» досліджує стильову поведінку як якісну ознаку сценічної пластики актора.

Специфіку використання пластичних засобів у процесі створення сценічного образу, на основі аналізу відомих методів акторського перевтілення, досліджує О. Хлистун $(2017$, с.100) у публікації «Особливості застосування пластичних та мовних засобів у процесі створення сценічного образу: мистецтвознавчий аналіз методів акторського перевтілення». 
Bulletin of Kyiv National University of Culture and Arts

Series in Stage Art

Поняття «пластика», «пластичність», «пластична виразність» $€$ відносно новими в театральній лексиці. Сформувавшись наприкінці XIX ст. як складова акторської майстерності, поняття остаточно затвердилися завдяки твердженню О. Островського (1952, с.165): «актор є пластичний художник». Однак у XIX ст. пластичність сприймали лише як складову майстерності актора у вирішенні зовнішнього малюнку, з особливим, «суворим відпрацюванням техніки» (Островский, 1952, с.167) виконання, із дотриманням класицистичних канонів. «Хто не може позбутись своїх звичних жестів, той не актор», - писав О. Островський (1952, с.165). Е. Манзарханов (2006, с.3-4) стверджує, що «практично у будь-якому виді мистецтва тою чи іншою мірою пластика присутня як невіддільний компонент таких естетичних категорій, як краса, прекрасне, гармонія».

Мистецтвознавець робить висновок, що пластика - це одна з властивостей внутрішнього та зовнішнього світу, яка безпосередньо пов'язана зі способом його сприйняття людиною та з її унікальною здатністю відтворювати у своїй свідомості сприйняті через звук, слово, лінію, малюнок, рух художні образи. Автор наводить слова Аристотеля, який стверджував, що «наслідування властиве людині з дитинства, і саме тим вона відрізняється від інших тварин, що найбільше здатна наслідувати, до того ж усі продукти наслідування усім приносять задоволення», та розрізняє окремі види мистецтва залежно від того, «чим саме здійснюється наслідування, або тим, чому саме наслідують - поет, драматург, він же ж постановник вистави, - ритмом, словом, гармонією та хореографією; танцюристи засобами виразних, ритмічних рухів відтворюють характери, душевні стани та дії» (Глумова-Глухарева, 1966, с.32). Е. Манзарханов $(2006$, с.4) фокусує увагу на тому, що протягом усієї історії постійними та єдиними можливостями для пластичної виразності в європейських акторів були лише танець і пантоміма.

На думку Т. Вільямса (1984, р.299), пластичність впливає на виразність сценічної дії, сприяє розкриттю теми, характеристик персонажів, а також додає художності сценічному твору через урізноманітнення сценічної лексики та створення поетичної правди.

Поступово поняття «пластична культура актора» стає ознакою професійної майстерності актора в роботі над створенням цілісного сценічного образу (Торгашов, 2013, с.388). Перевтілюючись, актор шукає в собі ті психофізичні якості, що характеризують створюваний ним образ, заглиблюючись у процес формування «людського тіла» і «людського духу» ролі.

С. Маркова $(2009$, с. 26) наголошує на нетотожності понять «пластика» та «пластична культура», оскільки друге належить до ширшої, власне, культурологічної наукової категорії. Сценічного персонажа глядач сприймає як через словесну, так і через пластичну дію; відповідно сценічний зоровий образ актор створює через використання засобів пластики, а життя персонажа на сцені стає логічною послідовністю дій, реалізованих у пластичній формі.

Г. Морозова $(1998$, с.8) наголошує, що пластична форма вистави, ії театральнохудожня складова в глядацькому сприйнятті залежить від пластичної культури актора та від його майстерності опанування сценічною пластикою. Талант актора, втілений у створеному ним пластичному малюнку ролі, зумовлюється 
Вісник Київського національного університету культури і мистецтв.

Серія: Сценічне мистецтво

виробленням і тренуванням психічних та психофізичних навичок, що розвивають пластичність тілесного апарату та здатність втілювати на сцені будь-яке пластичне рішення. Отож, можемо стверджувати, що пластичність є однією зпровіднихпрофесійних якостей, які характеризують рівень пластичної культури актора.

А. Дрознін (2004, с.25) стверджує, що театральне мистецтво - це окремий вид мистецтва, в якому не танець, а сценічна пластика - «своєрідний дієвий каркас, в якому живе актор» - $є$ формотворчою тренінговою системою. Саме через пластичний малюнок ролі актор шукає логіку побудови еволюції ролі від початку і до фіналу. Таким чином досягається органічний зв'язок зовнішнього пластичного малюнку та внутрішнього стану персонажа.

В. Ніжельський $(2015$, с.53) трактує тілесну виразність або виразність рухів як особливий тип рухової діяльності, що передбачає як біомеханічний, так і естетичний вимір руху в сценічному часопросторі (у розумінні візуального сприйняття його глядачем). Пластична складова, що передбачає різні форми руху або пози $€$ провідною характеристикою у виразності рухової діяльності.

Пластична культура як комплекс спеціальних теоретичних знань та практичних навичок хореографічно-пластичного та рухового характеру, необхідних актору для творчого осмислення пластичного образу персонажа.

Термін «жест» походить від латинського слова «gestus», яке має багато визначень, передусім - «тримати себе», що на думку А. Арустамян (1999, с.28), засвідчує означення жесту в його фізичному, зовнішньому прояві як «постановка тіла у просторі», а також в його активному початку - «тримати себе в руках»; «спосіб як хтось рухається» - манера поведінки людини, пластична своєрідність позиціювання себе самого іншим в конкретних умовно заданих ситуаціях і при зовнішніх обставинах, що не залежать від людини.

У цьому разі жест - елемент культури, що виражає конкретну історичну добу або локальний соціальний прошарок суспільства (Блазис, 1937, с.22); «положення тіла або поза» - будь-яка зовнішньо статична фіксована позиція з динамічним початком, у результаті чого вираження набуває нового сенсу (Богданов, 1997, с.76); «рух тіла» або «положення тіла» - жест містить кілька функцій у своєму зовнішньому, пластичному прояві: просторово-динамічну та процесуальну в часі та просторово-статичну, закріплену в часі; «дія частинами тіла» - визначення, що на думку дослідників, розкриває не тільки фізичну природу жесту, а й виявляє сутнісну характеристику жесту, тобто його дієвість, жест вже не просто розглядається як рух заради руху, а як цілеспрямована сенсові акція (Брук, 1976, с.32); «жестикуляція» - у другій половині XIX ст. слово «gesticulatio» перекладалося як «манірний, смішний рух тілом» від «gesticula» («гестикула») - пантомімістика, звідси «gesticulari» - виражати рухом тіла (Быховская, 1997, с.54); «пантомімний рух тіла» (Ваганова, 1980, с.76).

Художній сценічний жест як пластико-просторова конфігурація тілесності, наділена семіотично артикульованою вагомістю (Fischer-Lichte and Bharucha, 2011), культурний феномен, який є стійким знаком у цій культурній традиції, освоюється в процесі соціалізації та наділений стабільною семантикою, дуже складний 
через багатозначність, що має особливе значення в процесі створення образу. Жест несе в собі емоційно-духовний сенс, який декодує глядач.

Варто зазначити, що декодування і точне прочитання жестів або жесту може відбуватися лише в конкретно заданому контексті. Саме за таких умов жест ніби звучить у просторі чітко визначено, оскільки набуває конкретного значення. Художня інформація, яка також має власну специфіку (певне поєднання ідейного та чуттєвого), матеріалізується в сценічному жесті, сповнюючи його як думкою, так і емоцією. Це у свою чергу засвідчує важливість наявності спеціально підібраної дії при пантомімічній побудові. Виконавці $€$ репрезентаторами досвіду персонажа або предмета, який виникає у процесі взаємодії з його особистісними переживаннями або іншими об'єктами та суб'єктами, проживаючи його як на фізичному, так і на психічному та метафізичному рівнях (Никонова, 2015, с.50-55).

Транслюючи узагальнені переживання певного досвіду, актор вибудовує дію виключно на фізичному вираженні почуттів, відчуттів, емоційних станів та інших психічних явищ, звертається передусім до особистісного тілесного досвіду глядача, викликаючи специфічний відгук на побачене. Відтак, процес художньої взаємодії можемо порівняти з актом невербальної комунікації, оскільки тіло актора відтворює фізичне кодування психічних явищ, а глядач у свою чергу декодує його соматично.

Жест - виразний рух рукою, який В. Лоскутов $(1999$, с.62) визначає як функцію певної частини тіла; за ритмом, темпом, рельєфом та окресленням визначає предмети, яких не існує, з якими людина діє та яким керує, поєднує їх та надає сенс. Жест може бути утилітарним і передавати різні психологічні стани людини (страх, радість, страждання тощо), а також виражати образ, ідею або навіть діяти в більш загостреній формі.

Дослідник поділяє жести на три групи:

- ілюстративні, або зображальні (пов'язані з мовою, є їі доповненням, означують об'єм, вид, розмір або спосіб використання предметів, про які йде мова, а також уточнюють поняття);

- умовні (ілюструють, але не замінюють мову - церемоніальні та ритуальні жести, своєрідні пластичні ієрогліфи);

- психологічні або емоційні (відображають ставлення людини до явищ зовнішнього світу, виражають різноманітні емоції та відтінки почуттів) (Лоскутов, 1999, c.70).

На основі чотирьох груп жестів:

- жести, що викликані безпосередньою реакцією організму на явища навколишнього середовища;

- жести, що сформувалися за умов певного життєвого устрою;

- жести зображальні;

- жести умовні, що зазвичай побутують серед людей, пов'язаних професійними, територіальними та іншими особливостями, дослідники умовно поділяють пантоміму на три групи: побутову, дієву та умовно-символічну (Дживелегов, 1962, c.29-32). 
Виразність - це не тільки якість, що характеризує естетичний аспект рухової діяльності, а й комплекс специфічних рухів. На думку В. Ніжельського (2016а, с.170), поняття «виразний рух» уміщує три компоненти:

- наявність змісту (що саме має бути виражено) - соціальний жест, демонстрація емоційного стану, окреслення порядку дій, рух за певним естетичним каноном, виконання якого $є$ вираженням краси руху в пантомімі;

- наявність об'єкта сприйняття виразності, реципієнта для сценічної діяльності, оскільки лише він може оцінити якість та інтенсивність виразності руху, сприйняти, відчути й осмислити його зміст;

- можливість рухової активності з боку суб'єкта виразності (виконання змістовних рухів, спрямованих на об'єкт сприйняття; реалізація виражального руху).

У такому разі характерними рисами виражального руху є пластичність, витонченість, злитість, артистичність, емоційне наповнення, осмисленість та невимушеність.

Пластичність як рухово-координаційну якість, на відміну від інших характеристик, можемо презентувати як фізичний сенс виражального руху, головну частину його структури, що виявляє і психофізичні якості.

Ії ознаками є:

- ступінь внутрішнього відчуття характеру рухової дії;

- наявність емоційного підйому;

- свобода рухів;

- досягнення органічного поєднання з музичним супроводом;

- здатність передавати художній образ через музичний супровід і рухи;

- наявність контакту з глядачем.

Зауважимо, що на думку В. Ніжельського $(2015$, с.170), виразність $є$ необхідною властивістю пластичних рухів, натомість пластичний рух не обов'язково буде виразним.

Наукова новизна полягає в теоретичному обґрунтуванні специфіки сценічної пластики у виконавському мистецтві актора відповідно до актуальних світових тенденцій.

\section{Висновки}

Пластика охоплює широку галузь людської діяльності, зокрема мистецької. Пластичність у сценічному мистецтві - це засіб художньої виразності, що дає змогу наочно виявити внутрішній зміст через зовнішню форму. Пластичність - головна якість, що характеризує рівень пластичної культури актора.

Вплив засобів пластичної виразності актора на емоції глядачів підпорядковується розв'язанню сенсових, тематичних та естетичних завдань, оскільки сценічна пластика $є$ однією з провідних складових художнього образу. Усі сценічні пози, жести та рухи взаємопов'язані з психофізичним станом актора. Пластичну виразність актора варто розглядати як пластику сценічної дії, що виходить з драматургічного змісту сценічного твору. Спираючись на драматургію, будується логіка пластичного рішення художнього образу вистави та персонажа. 
У площині аналізу складових майстерності актора сценічна пластика може розглядатися як певна система спеціальних знань, сукупність фізичних навичок, умінь і психологічних якостей актора, моральних та естетичних категорій, що сприяє художньому втіленню образу. Пластична майстерність актора під час створення пластичного малюнку ролі забезпечує передусім тренування психічних і психофізичних навичок, що сприяє розвитку пластичності тілесного апарату, здатності пристосовуватися до виконання будь-якого пластичного завдання, що визначається внутрішньою або зовнішньою художньою необхідністю.

Сценічна пластика в контексті акторської майстерності розглядається як комплекс спеціальних знань, сукупність фізичних навичок, умінь і психологічних якостей актора, моральних та естетичних категорій, що сприяє художньому втіленню образу. Двоїста природа пластичної виразності: тілесна (у розумінні моторна) та чуттєва (тобто, психоемоційна), що дозволяє презентувати її як своєрідне художнє зображення. Пластична культура як комплекс спеціальних теоретичних знань і практичних навичок хореографічно-пластичного та рухового характеру, необхідних актору для творчого осмислення пластичного образу персонажа.

\section{СПИСОК ПОСИЛАНЬ}

Абрамович, О.О. та Кудренко, А.А., 2019. Сценічна пластика в контексті сучасного акторського мистецтва. Молодий вчений, 9(1), с.133-136. https://doi.org/10.32839/23045809/2019-9-73-29.

Арустамян, А.В., 1999. Жест в культуре и искусстве: междисциплинарный анализ. Кандидат искусствоведения. Санкт-Петербургская государственная академия театрального искусства.

Благова, Т., 2014. Хореографічні підготовка в системі театральної освіти України. Естетика і етика педагогічної дії, 8, с.100-110.

Блазис, К., 1937. Искусство танца : извлечение из книги "Manuel complet de la tanse". Перевод с французского О.Н. Брошниовской. Москва: Искусство.

Богданов, К.А., 1997. Очерки по антропологии молчания: Ноmo Tacenso. Санкт-Петербург: РХГИ.

Брук, П., 1976. Пустое пространство. Москва: Прогресс.

Бусол, А., Бусол, В., Кроншталь, Г. та Цибульський, М. 2014. Сценічний рух як складова професійноїпідготовки студентів спеціальності акторська майстерність. Фізична культура, спорт та здоров'я нації, 17, с.34-41.

Быховская, И.М., 1997. «Человек телесный» в социокультурном пространстве и времени: Очерки социальной и культурной антропологии. Москва: ЮН.

Ваганова, А.Я., 1980. Основы классического танца. Ленинград: Искусство.

Глумова-Глухарева, Э.И., 1966. Западный театр сегодня. Москва: Искусство.

Громов, Ю.И., 1976. Воспитание пластической культуры актера средствами танца. Москва: Профиздат.

Гула, Є., 2017. Пластика в мистецтві України. Народознавчі зошити, 4 (136), с.914-919. https://doi.org/10.15407/nz2017.04.914. 
Дживелегов, А.К., 1962. Народная итальянская комедия. Москва: Издательство Академии наук СССР.

Дрознин, А., 2004. Физический тренинг актера по методике Дрознина. Москва: Всероссийский Центр Художественного Творчества.

Зыков, А., 2008. Задачи пластического воспитания актеров в контексте музики и актерского мастерства и примеры их решения посредством танцевального искусства XX века. В: Инновационные технологии развития образовательного пространства художественного ВуЗа. Материалы Международной конференции. Саратов. Россия, с. 221-230.

Касьянова, О., 2015. Особливості пластично-хореографічної підготовки співака-актора оперного жанру. Київське музикознавство, 51, с.52-62.

Лоскутов, В.В., 1999. Психология пантомимы: феноменология и закономерности. Вестник Санкт-Петербургского университета, 1, 6, с.58-70.

Манзарханов, Э.Е., 2006. Особенности пластического искусства в драматургическом театре Запада и Востока. Автореферат дисертаций кандидата искусствоведения. ВосточноСибирская государственная академия культуры и искусств.

Маркова, С.В., 2009. Пластическая режисура: проблемы формирования пластической культуры режиссера и актера. Культурная жизнь Юга России, 4 (33), 25-26.

Мартынова, О.И., 2000. Сохранение традиций пластического воспитания актера в театральной школе. Вестник Омского университета, 3, с.80-82.

Морозова, Г.В., 1998. Пластическое воспитание актера. Москва: Терра спорт.

Нижельской, В.А., 2015. Выразительное движение как взаимосвязь двигательных способностей и пластических качеств актера. Вестник Казанского государственного университета культуры и искусств, 4/1, с.52-56.

Нижельской, В.А., 2016а. О физическом и художественном аспектах выразмтельного движения. Театр. Живопись. Кино Музыка, 2, с. 165-172.

Нижельской, В.А., 2016b. Пластическое воспитание будущих актеров как фактор культурного преобразования физических действий в семиотический текст. Вестник Кемеровского государственного университета культуры и искусств, 35, с.189-193.

Никонова, С.Б., 2015. «Эстетический человек» и новые формы искусства. Вопросы культурологи, 1, с.50-55.

Островский, А.Н., 1952. О театральных школах. В: Полное собрание сочинений. Москва: Государственное издательство художественной литературы. Т. 12. Статьи о театре. Записки. Речи 1859-1886, с.162-174.

Разночинцева, М.А., 2013. Роль пластики (сценического движения) в обучении актурской профессии. Театр. Живопись. Кино. Музыка, 4, с.121-129.

Соломкина, Т.А., 2015. Пластическая выразительность немецкого экспрессионистского актера на сцене и на экране. 1914-1921 гг. Вестник Академии Русского балета им. А. Я. Вагановой, 1, с.148-154.

Старостін, Ю., 2016. Акторський тренінг: його зміст та основа. Науковий вісник Київського національного університету театру, кіно і телебачення імені І.К. Карпенка-Карого, 19, с.201-204. Торгашов, В.Н., 2013. Дефицит пластической культуры актера - проблема современного актерского образования. Ученые записки Орловского государственного университета, 2 (54), c.387-389. 
Хлистун, О., 2017. Особливості застосування пластичних та мовних засобів у процесі створення сценічного образу: мистецтвознавчий аналізметодів акторськогоперевтілення. Вісник КНУКіМ. Серія: Мистецтвознавство, 37, с.98-114.

Fischer-Lichte, E. and Bharucha, R., 2011. Dialogue: Erika Fischer-Lichte, Erika and Rustom Bharucha. Textures. [online] Avialable at: <http://www.textures-platform.com> [Accessed 15 September 2020].

Williams, T., 1984. Production Notes Sweet Bird of Youth; A Streetcar Named Desire; The Glass Menagerie, by Tennessee Williams. London: Penguin Books, pp. 229-231.

\section{REFERENCES}

Abramovych, 0.0. and Kudrenko, A.A., 2019. Stsenichna plastyka v konteksti suchasnoho aktorskoho mystetstva [Stage sculpture in the context of modern acting]. Molodyi vchenyi, 9(1), pp.133-136. https://doi.org/10.32839/2304-5809/2019-9-73-29.

Arustamian, A.V., 1999. Zhest $v$ kulture $i$ iskusstve: mezhdistciplinarnyi analiz [Gesture in culture and art: an interdisciplinary analysis]. Ph.D. in History of Arts. Russian State Institute of performing arts.

Blahova, T., 2014. Khoreohrafichni pidhotovka v systemi teatralnoi osvity Ukrainy [Choreographic training in the system of theater education in Ukraine]. Estetyka i etyka pedahohichnoi dii, 8, pp.100-110. Blazis, K., 1937. Iskusstvo tantca : izvlechenie iz knigi "Manuel complet de la tanse" [The Art of Dance: Extract from the book "Manuel complet de la tanse"]. Translated from French by O.N. Broshniovskaya. Moscow: Iskusstvo.

Bogdanov, K.A., 1997. Ocherki po antropologii molchaniia: Homo Tacenso [Essays on the anthropology of silence: Homo Tacenso]. St. Petersburg: RKhGI.

Bruk, P., 1976. Pustoe prostranstvo [Empty space]. Moscow: Progress.

Busol, A., Busol, V., Kronshtal, H. and Tsybulskyi, M. 2014. Stsenichnyi rukh yak skladova profesiinoi pidhotovky studentiv spetsialnosti aktorska maisternist [Stage movement as a component of professional training of students majoring in acting]. Fizychna kultura, sport ta zdorovia natsii, 17, pp.34-41.

Bykhovskaia, I.M., 1997. "Chelovek telesnyi" v sotciokulturnom prostranstve $i$ vremeni: Ocherki sotcialnoi $i$ kulturnoi antropologii ["Bodily man" in socio-cultural space and time: Essays on social and cultural anthropology]. Moscow: luN.

Droznin, A., 2004. Fizicheskii trening aktera po metodike Droznina [Physical training of the actor according to the Droznin method]. Moscow: Vserossiiskii Tcentr Khudozhestvennogo Tvorchestva.

Dzhivelegov, A.K., 1962. Narodnaia italianskaia komediia [Italian folk comedy]. Moscow: Izdatelstvo Akademii nauk SSSR.

Fischer-Lichte, E. and Bharucha, R., 2011. Dialogue: Erika Fischer-Lichte, Erika and Rustom Bharucha. Textures. [online] Avialable at: <http://www.textures-platform.com> [Accessed 15 September 2020].

Glumova-Glukhareva, E.I., 1966. Zapadnyi teatr segodnia [Western theater today]. Moscow: Iskusstvo.

Gromov, lu.I., 1976. Vospitanie plasticheskoi kultury aktera sredstvami tantca [Education of the actors plastic culture by means of dance]. Moscow: Profizdat. 
Hula, Ye., 2017. Plastyka v mystetstvi Ukrainy [Plastic art in the art of Ukraine]. Narodoznavchi zoshyty, 4(136), pp.914-919. https://doi.org/10.15407/nz2017.04.914.

Kasianova, O., 2015. Osoblyvosti plastychno-khoreohrafichnoi pidhotovky spivaka-aktora opernoho zhanru [Features of plastic and choreographic training of the singer-actor of the opera genre]. Kyivske muzykoznavstvo, 51, pp.52-62.

Khlystun, O., 2017. Osoblyvosti zastosuvannia plastychnykh ta movnykh zasobiv u protsesi stvorennia stsenichnoho obrazu: mystetstvoznavchyi analiz metodiv aktorskoho perevtilennia [Features of the use of plastic and linguistic means in the process of creating a stage image: art analysis of methods of actors reincarnation]. Bulletin of the Kiev National University of Culture and Arts. Series in Arts, 37, pp.98-114.

Loskutov, V.V., 1999. Psikhologiia pantomimy: fenomenologiia i zakonomernosti [Psychology of pantomime: phenomenology and patterns]. Vestnik Sankt-Peterburgskogo universiteta, 1, 6, pp.58-70.

Manzarkhanov, E.E., 2006. Osobennosti plasticheskogo iskusstva v dramaturgicheskom teatre Zapada i Vostoka [Features of plastic art in the drama theater of the West and the East]. Abstract of dissertations of the candidate of art history. East Siberian State Academy of Culture and Arts. Markova, S.V., 2009. Plasticheskaia rezhisura: problemy formirovaniia plasticheskoi kultury rezhissera i aktera [Plastic directing: problems of the formation of the plastic culture of the director and the actor]. Kulturnaia zhizn luga Rossii, 4 (33), pp.25-26.

Martynova, O.I., 2000. Sokhranenie traditcii plasticheskogo vospitaniia aktera $v$ teatralnoi shkole [Preserving the traditions of the actors plastic education in the theater school]. Vestnik Omskogo universiteta, 3, pp.80-82.

Morozova, G.V., 1998. Plasticheskoe vospitanie aktera [Plastic education of the actor]. Moscow: Terra sport.

Nikonova, S.B., 2015. "Esteticheskii chelovek" i novye formy iskusstva ["Aesthetic man" and new forms of art]. Voprosy kulturologi, 1, pp.50-55.

Nizhelskii, V.A., 2016. O fizicheskom i khudozhestvennom aspektakh vyrazmtelnogo dvizheniia [On the physical and artistic aspects of expressive movement]. Teatr. Zhivopis. Kino Muzyka, 2, pp.165-172.

Nizhelskoi, V.A., 2015. Vyrazitelnoe dvizhenie kak vzaimosviaz dvigatelnykh sposobnostei i plasticheskikh kachestv aktera [Expressive movement as the relationship of motor abilities and an actors plastic qualities]. Vestnik Kazanskogo gosudarstvennogo universiteta kultury i iskusstv, 4/1, pp.52-56.

Nizhelskoi, V.A., 2016. Plasticheskoe vospitanie budushchikh akterov kak faktor kulturnogo preobrazovaniia fizicheskikh deistvii v semioticheskii tekst [Plastic education of future actors as a factor in the cultural transformation of physical actions into a semiotic text]. Vestnik Kemerovskogo gosudarstvennogo universiteta kultury $i$ iskusstv, 35, pp.189-193.

Ostrovskij, A.N., 1952. O teatralnyh shkolah [About theater schools]. In: Polnoe sobranie sochinenij [Complete Works]. Moscow: Gosudarstvennoe izdatelstvo hudozhestvennoj literatury. T. 12. Stati o teatre. Zapiski. Rechi 1859-1886 [Articles about the theater. Notes. Speeches 1859-1886], pp.162-174.

Raznochintceva, M.A., 2013. Rol plastiki (stcenicheskogo dvizheniia) v obuchenii akturskoi professii [The role of plastics (stage movement) in teaching acting profession]. Teatr. Zhivopis. Kino. Muzyka, 4, pp.121-129. 
Solomkina, T.A., 2015. Plasticheskaia vyrazitelnost nemetckogo ekspressionistskogo aktera na stcene i na ekrane. 1914-1921 gg. [Plastic expressiveness of the German expressionist actor on stage and on the screen. 1914-1921] Vestnik Akademii Russkogo baleta im. A. Ia. Vaganovoi, 1, pp.148-154.

Starostin, Yu., 2016. Aktorskyi treninh: yoho zmist ta osnova [Acting training: its content and basis]. Naukovyi visnyk Kyivskoho natsionalnoho universytetu teatru, kino i telebachennia imeni I.K. Karpenka-Karoho, 19, pp.201-204.

Torgashov, V.N., 2013. Defitcit plasticheskoi kultury aktera - problema sovremennogo akterskogo obrazovaniia [Deficiency of the actors plastic culture is the problem of modern acting education]. Uchenye zapiski Orlovskogo gosudarstvennogo universiteta, 2 (54), pp.387-389.

Vaganova, A.la., 1980. Osnovy klassicheskogo tantca [Basics of classical dance]. Leningrad: Iskusstvo.

Williams, T., 1984. Production Notes Sweet Bird of Youth; A Streetcar Named Desire; The Glass Menagerie, by Tennessee Williams. London: Penguin Books.

Zykov, A., 2008. Zadachi plasticheskogo vospitaniia akterov v kontekste muziki i akterskogo masterstva i primery ikh resheniia posredstvom tantcevalnogo iskusstva XX veka [The tasks of plastic education of actors in the context of music and acting and examples of their solution through the dance art of the twentieth century]. In: Innovatcionnye tekhnologii razvitiia obrazovatelnogo prostranstva khudozhestvennogo VUZa [Innovative technologies for the educational space development of an art university]. Materials of the International Conference. Saratov. Russia, pp.221-230.

\title{
ТЕОРЕТИКО-МЕТОДОЛОГИЧЕСКИЕ АСПЕКТЫ ПЛАСТИЧЕСКОЙ ВЫРАЗИТЕЛЬНОСТИ В МАСТЕРСТВЕ АКТЕРА
}

\author{
Елена Абрамович ${ }^{1 a}$, Алина Кудренко ${ }^{2 b}$ \\ ${ }^{1}$ кандидат педагогических наук, доцент; \\ e-mail: elenaabramovic20@gmail.com; ORCID: 0000-0002-4814-6709 \\ ${ }^{2}$ магистр; e-mail: kudrenko.alina@gmail.com; ORCID: 0000-0002-0288-8061 \\ а Киевский национальный университет культуры и искусств, Киев, Украина

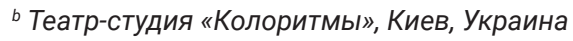

\section{Аннотация}

В статье рассматривается пластическая культура как составная сценического искусства в плоскости создания пространственных форм художественного произведения, индивидуальной творческой трактовки и внутреннего состояния актера. Пластика рассматривается как эффективный инструмент воспитания актера и формирования его внешней техники, с чем связаны новые поиски и эксперименты. Целью работы является освоение теоретических знаний, принципов пластического мастерства современного актера. Методология заключается в системном использовании комплексных методов 
исследования пластической культуры актера: историко-культурного - для исследования исторической динамики развития пластической культуры актера; аналитического для обработки культурологической, искусствоведческой и театроведческой научной литературы, а также обработки архивных материалов; источниковедческого - для изучения базы источников исследования; типологического метода, содействующего выявлению факторов, влияющих на формирование сценической пластики актера; метода научного наблюдения и анализа, позволяющего выяснить особенности пластической выразительности в контексте ее двойственной природы (как телесной, так и чувственной); системного метода, содействующего исследованию особенностей интеграции составляющих пластической культуры в процессе создания сценического образа; метода теоретического обобщения для подведения итогов исследования. Научная новизна заключается в теоретическом обосновании специфики сценической пластики в исполнительском искусстве актера в соответствии с актуальными мировыми тенденциями. Выводы. Пластическое мастерство актера (создание пластического рисунка роли) обеспечивает прежде всего тренировка психических и психофизических навыков, способствующих совершенствованию пластичности телесного аппарата исполнителя, способности адаптироваться к выполнению любых пластических задач. Пластичность - это главное качество, характеризующее уровень пластической культуры актера. Сценическая пластика в мастерстве актера - это система взаимосвязанных знаний, физических навыков и умений, психологических, нравственных и эстетических качеств исполнителя, способствующих созданию художественного сценического образа. Двойственная природа пластической выразительности: телесная (в смысле моторная) и чувственная (то есть психоэмоциональная), позволяющая представить ее как своеобразное художественное изображение. Пластическая культура это комплекс специальных теоретических знаний и практических навыков танцевальнопластического и двигательного характера, необходимых актеру для творческого осмысления пластического образа персонажа.

Ключевые слова: пластическое мастерство актера; пластический рисунок роли; художественный образ 


\title{
THEORETICAL AND METHODOLOGICAL ASPECTS OF PLASTIC EXPRESSION IN THE ACTOR'S SKILL
}

\author{
Olena Abramovych ${ }^{1 a}$, Alina Kudrenko ${ }^{2 b}$ \\ ${ }^{1}$ Ph.D. in Pedagogical Sciences, Associate Professor; \\ e-mail: elenaabramovic20@gmail.com; ORCID: 0000-0002-4814-6709 \\ ${ }^{2}$ Master; e-mail: kudrenko.alina@gmail.com; ORCID: 0000-0002-0288-8061 \\ a Kyiv National University of Culture and Arts, Kyiv, Ukraine \\ ' Studio Theater "Kolorytmy", Kyiv, Ukraine
}

\section{Abstract}

The article considers plastic culture as a component of performing arts in the plane of creating spatial forms of artwork of, individual creative interpretation and the actor's inner state. Plastic is considered as an effective tool for educating the actor and the formation of his external technique, which is associated with the latest research and experiments. The purpose of the article is to master the theoretical knowledge, the principles of plastic skill of the modern actor. The methodology consists in the systematic use of complex methods of studying the actor's plastic culture: historical and cultural is to study the historical dynamics of the of plastic culture development of the actor; analytical is for the study of cultural, art and theater scientific literature, as well as the processing of archival materials; source study is to study the source base of the study; typological method that helped to identify factors that affect the formation of theatrical performance of the actor; the method of scientific observation and analysis, which made it possible to clarify the features of plastic expression in the context of its dual nature (both physical and sensory); system method, which contributed to the study of the features of the integration of the components of plastic culture in the process of creating a stage image; method of theoretical generalization is to summarize the study. Scientific novelty lies in the theoretical substantiation of the specifics of stage sculpture in the performing arts of the actor in accordance with current world trends. Conclusions. First of all, the actor's plastic skill (creation of a plastic drawing of a role) provides training of mental and psychophysical skills that promotes improvement of plasticity of a physical device of the executor, ability to adapt to performance of any plastic tasks. Plasticity is the main quality that characterizes the actor's level of plastic culture. Stage sculpture in the actor's skill is a system of interconnected knowledge, physical skills and abilities, psychological, moral and aesthetic qualities of the performer, which contribute to the creation of an artistic stage image. The dual nature of plastic expression: bodily (in the sense of motor) and sensual (i.e. psycho-emotional), which allows you to present it as a kind of artistic image. Plastic culture is a set of special theoretical knowledge and practical skills of dance-plastic and motor nature, necessary for the actor to comprehend the plastic image of the character creatively. Keywords: plastic skill of the actor; plastic drawing of the role; artistic image 